\title{
TREATMENT OF METAL-LADEN HAZARDOUS WASTES WITH \\ ADVANCED CLEAN COAL TECHNOLOGY BY-PRODUCTS
}

\author{
QUARTERLY TECHNICAL PROGRESS REPORT
}

DECEMBER 30, 1997 - MARCH 30, 1998

\author{
James T. Cobb, Jr. \\ Ronald D. Neufeld \\ Jana Agostini \\ School of Engineering \\ University of Pittsburgh
}

May 10, 1999

Award No. DE-FC21-94MC31175

For: U. S. Department of Energy Federal Energy Technology Center

Morgantown, West Virginia 
This Quarterly Technical Progress Report was prepared with the support of the U.S. Department of Energy, under Cooperative Agreement No. DE-FC21-94MC31175. However, any opinions, findings, conclusions, or recommendations expressed herein are those of the authors and do not necessarily reflect the views of the DOE. 


\section{DISCLAIMER}

This report was prepared as an account of work sponsored by an agency of the United States Government. Neither the United States Government nor any agency thereof, nor any of their employees, make any warranty, express or implied, or assumes any legal liability or responsibility for the accuracy, completeness, or usefulness of any information, apparatus, product, or process disclosed, or represents that its use would not infringe privately owned rights. Reference herein to any specific commercial product, process, or service by trade name, trademark, manufacturer, or otherwise does not necessarily constitute or imply its endorsement, recommendation, or favoring by the United States Government or any agency thereof. The views and opinions of authors expressed herein do not necessarily state or reflect those of the United States Government or any agency thereof. 


\section{DISCLAIMER}

\section{Portions of this document may be illegible in electronic image products. Images are produced from the best available original document.}




\section{TABLE OF CONTENTS}

$\begin{array}{lc}\text { Executive Summary } & 1\end{array}$

Introduction

Laboratory and Field Work 4

Reports and Presentations 5

$\begin{array}{lc}\text { Outside Contacts } & 6\end{array}$

$\begin{array}{lr}\text { Administrative Aspects } & 7\end{array}$

$\begin{array}{ll}\text { Plan for the Next Quarter } & -\end{array}$

Appendix A - Letter of Recommitment to the Project by MAX Environmental 10 Technologies, Inc.

Appendix B - Letter to FETC on Projects at the University of Pittsburgh Involving the Use of By-Products

Appendix C - Letter to Burns and Roe Service Corporation on a Potential Role for the University of Pittsburgh in the U.S.AID/U.S.DOE Interagency Program with India 


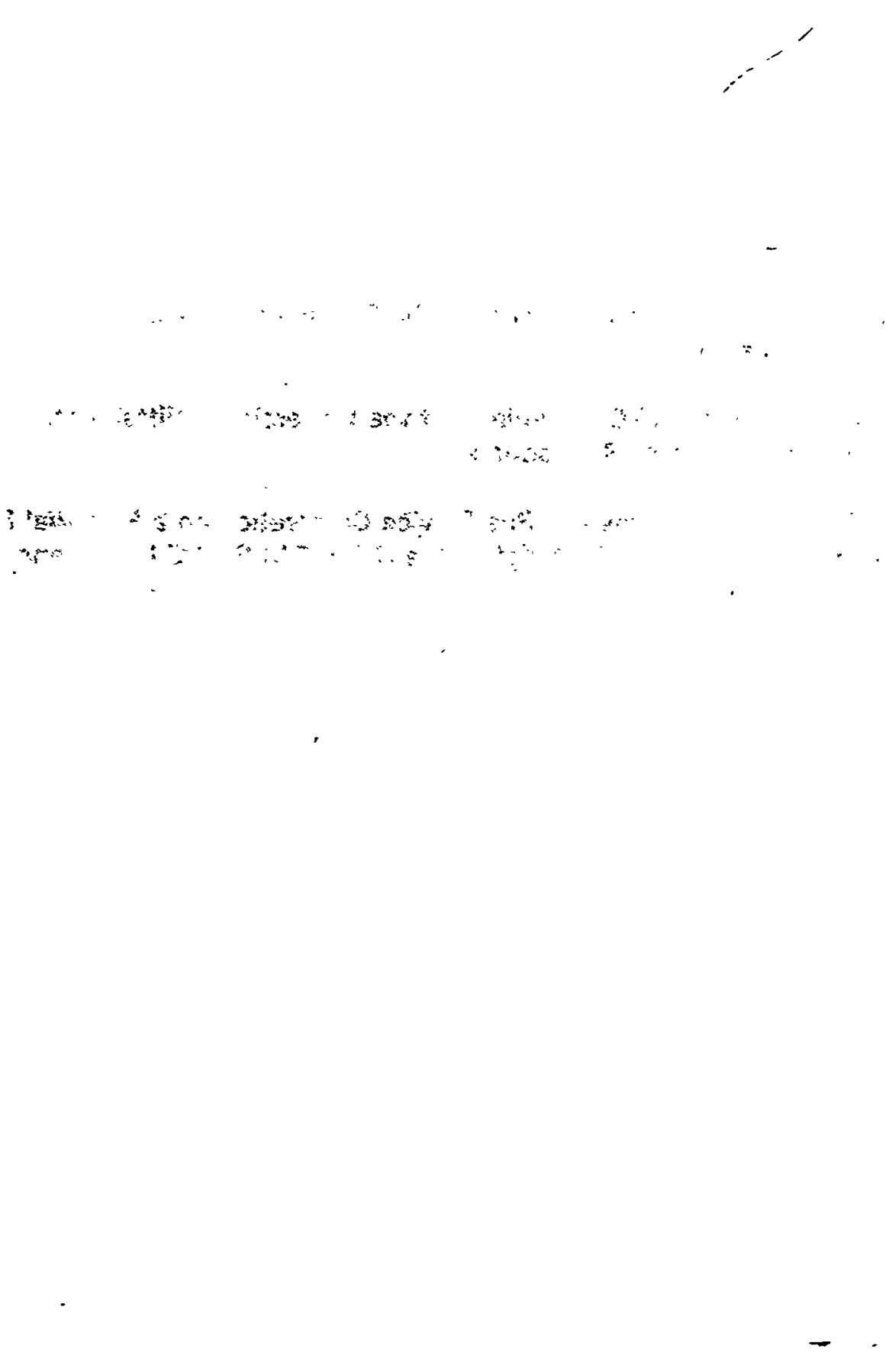




\section{EXECUTIVE SUMMARY}

During the tenth quarter of Phase 2, work continued on conducting scholarly work, preparing for field work, preparing presentations, and making additional outside contacts.

Scholarly Work

The graduate student assigned to this project from the Department' of Civil and Environmental Engineering has continued her work on evaluation of the lorg-term stability of Phase 1 samples.

Preparation for Field Work

MAX Environmental Technologies, Inc., formally rejoined the project team.

Work began on the detailed design of that portion of the new system to handle dusty treatment chemicals. The steps toward installation of this equipment and its initial use in the demonstration were outlined.

\section{Reports and Presentations}

An invitation was accepted to give a presentation at the annual FETC conference in July 1.998.

\section{Qutside Contacts}

In a letter to FETC the co-principal investigator described the projects at the University of Pittsburgh on coal combustion by-product utilization.

The principal investigator sent a letter to Burns and Roe Service Company describing the potential assistance of the University of Pittsburgh to the U.S.AID/U.S.DOE Interagency Program with India.

\section{Plans for the Next Quarter}

During the quarter from March 30 through June 30, 1998, work will continue on Tasks 4 and 5 of Phase 1 . The graduate student assigned to this project will continue her scholarly work during this quarter. 
Work on Task 1 of Phase 2 will continue. The principal investigator will maintain contact with MAX Environmental Technologies, Inc., as it plans the installation of equipment at the Mill Service Yukon Plant to conduct Phase 2 of the project. 


\section{INTRODUCTION}

This fourteenth quarterly report describes work done during the fourteenth three-month period of the University of Pittsburgh's project on the "Treatment of Metal-Laden Hazardous Wastes with Advanced Clean Coal Technology By-Products."

This report describes the activities of the project team during the reporting period. The principal work has focussed upon new laboratory evaluation of samples from Phase 1, discussions with MAX Environmental Technologies, Inc., on the field work of Phase 2, preparing presentations, and making and responding to two outside contacts. 


\section{LABORATORY AND FIELD WORK}

\section{Scholarly Activity}

Jana Agostini, the graduate student in the Civil and Environmental Engineering Department, continued her work in the environmental laboratories on the ninth floor of Benedum Engineering Hall. Preliminary results of her work were presented in the previous quarterly report. Further results will be presented in a project report at a later time.

\section{Preparation for Field Work}

MAX Environmental Technologies, Inc. (MAX), formally rejoined the project team via a letter of recommitment dated January 22, 1998. This letter is shown in Appendix A.

Work began this quarter by MAX on the detailed design of one portion of the new system at the Mill Service Yukon Plant (MSYP). When fully installed, the new system will allow MSYP to treat dusty wastes with dusty chemicals (including advanced clean coal technology by-products). At the beginning of the quarter it was expected that the entire system would be acquired immediately. However, a major investment at another MAX site required that the installation at MSYP be scaled back to include just the equipment to handle dusty treatment chemicals and to allow these to be used at the SWSS pits.

The steps to engaging this partial installation in the project are:

- detailed design of treatment chemical unloading section, silo, chemical transfer section and dust management system at the SWSS pits

- preparation of the air and solid waste permit applications for construction and operation of the partial system

- review of permit applications and issuance of permits

- construction of the partial system

- preparation of the task plan for Phase 2 of the project

The task plan will describe the acquisition of chemicals and wastes, the treatability and solidification study for each chemical/waste pair, the treatment of 20-30 tons of waste with 2-6 tons of chemicals in each batch in the SWSS pits, and the stabilization/solidification characterization of treated products. 


\section{REPORTS AND PRESENTATIONS}

On March 19 an invitation was received and accepted to make a presentation describing the project at the annual FETC conference in Morgantown on July 21-22, 1998 . The project team plans to provide a comprehensive review of Phase 1 and a summary of the many steps that have been necessary to conduct Phase 2 . 


\section{OUTSIDE CONTACTS}

\section{Suggestions for Other Projects with FETC}

On January 19 the co-principal investigator followed up on the discussion at the informal meeting on coal combustion by-product utilization in environmental remediation projects in western Pennsylvania on December 4, 1997 with a letter to FETC describing projects at the University of Pittsburgh involving the innovative use of by-products. This letter is reproduced in Appendix B.

\section{Projects in India}

In early February the principal investigator spoke at length with Dr. Radha Krishnan of SAIC about the U.S.AID/U.S.DOE Interagency Program with India. Dr. Krishnan encouraged the University of Pittsburgh to continue its dialog with FEC. about involvement in the program.

At mid-month in February, the principal and co-principal investigators met with $\mathrm{Dr}$. Krishnan and staff from Burns and Roe Service Company at FETC to consider in depth how the University might assist the Interagency Program. A vision for the University's assistance was provided in a letter to Dr. Roger Rao. This letter is reproduced in Appendix C. 


\section{ADMINISTRATIVE ASPECTS}

This section provides the monthly highlights, and closes by comparing progress with the milestone chart.

\section{Monthly Highlights}

Here are the highlights of the tenth. three-month period of the second phase of the project.

December 30,1997 - January 30, 1998

- MAX Environmental Technologies, Inc., officially rejoins the project team.

- Steps are outlined for installation of equipment for and initiation of the demonstration.

- Description of projects at the University on coal combustion by-product. utilization is provided to FETC.

January 30 - February 28,1998

- Discussions are held at FETC on the U.S.AID/U.S.DOE interagency Program with India.

February 28 - March 30. 1998

- Letter is sent to Burns and Roe Service Company describing potential assistance of the University of Pittsburgh for the U.S.AID/U.S.DOE Interagency Program with India.

- Invitation is accepted to give a presentation on the project at the annual FETC conference in July 1998.

\section{Comparison of Progress with Milestone Chart}

The following task for Phase 2 had been scheduled for completion during the first quarter of Phase 2:

- Task 1 - Test Plan for Phase 2

Task 1 still was not completed during the tenth period of this phase. The decision in early April 1996 by METC that an environmental assessment of the Phase 2 project at the Yukon plant of 
Mill Service, Inc. (MSI), would have to be conducted and the subsequent withdrawal in late April 1996 by MSI from Phase 2 necessitated a search for a new subcontractor to host and participate in the commercial test of Phase 2. MAX Environmental Technologies, Inc., has rejoined the project team and is designing modifications at the Mill Service Yukon Plant (MSYP) to enable it to enter this business area and carry out the field work on this project. The test plan for Phase 2 will be prepared shortly before the permits are in place for the installation of the equipment at MSYP for carrying out the demonstration.

Work continued on two tasks from Phase 1:

- Task 4 - Treatment of Metal-Laden Waste with CCT Solid By-Product

- Task 5 - Data Analysis

Work on Tasks 4 and 5 of Phase 1 will continue into the tenth quarter of Phase 2. The fourth by-product and the final three residues are no longer being actively sought. When the Phase 2 testing program is initiated, consideration will be given to reestablishing this activity. 


\section{PLAN FOR THE NEXT QUARTER}

During the quarter from March 30 through June 30, 1998, work will continue on Tasks 4 and 5 of Phase 1 . The graduate student assigned to this project will continue her scholarly work during this quarter.

Work on Task 1 of Phase 2 will continue. The principal investigator will maintain contact with MAX Environmental Technologies, Inc., as it plans the installation of equipment at the Mill Service Yukon Plant to conduct Phase 2 of the project. 


\section{APPENDIX A}

\section{LETTER OF RECOMMITMENT TO THE PROJECT BY MAX ENVIRONMENTAL TECHNOLOGIES, INC.}




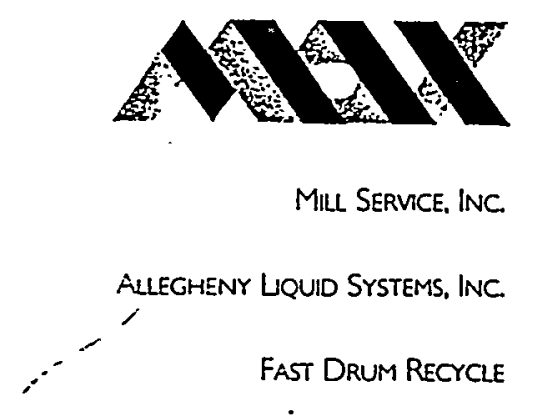

January 22, 1998

Mr. Michael M. Crouch, Director

Office of Research

University of Pittsburgh

350 Thackeray Hall

Pittsburgh, PA 15260.

\section{Dear Mr. Crouch:}

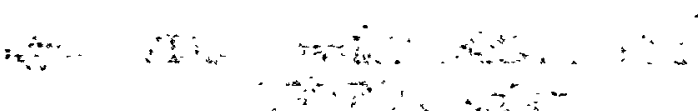

This is to confirm that MAX Environmental Technologies, Inc. (formerly known as "Mill Service, Inc.), will resume its participation as a subcontractor in the project on "Treatment of Metal-Laden Hazardous Waste with Advanced Clean Coal Technology By-Products," Contract No. DE-FC21-94-MC31175, which the Universty of Pittsburgh is conducting for the Federal Energy Technology Center of the U.S. Department of Energy.

As was noted in the letter of April 26, 1996, in which MAX exercised its option to terminate the subcontract agreement, MAX was pleased with the results of phase 1 of the project and with its participation in it. MAX had expected to continue as a subcontractor for phase 2, and was looking forward to doing so; however, we found that we-had to terminate the agreement as phase 2 was being planned, due to uncontrollable circumstances.

Those circumstances have recently changed, and MAX is happy to rejoin the project team. In doing so, it accepts all of the terms and conditions of the prior subcontract. It also accepts all currently valid elements of the Continuation Application for the project, dated June 9, 1995, which was submitted by the University to the U.S. Department of Energy prior to MAX's termination of the subcontract agreement on April 26, 1996. It should be noted, however, that certain aspects of the equipment, employees, and procedures used to treat hazardous wastes with advanced clean coal technology by products at the Mill Service Yukon Plant have changed during the intervening period. These changes will be reflected in the "Comprehensive Field-Scale Test Plan for Phase 2 from February 12, 1998 to March 31, 1999," which will be prepared by the project team during the coming 30 days, as well as the reed to obtain a permit. 
Mr. Michael M. Crouch

Page 2

January 21, 1998

We continue to believe that this project is needed to assist in developing appropriate new utilizations for coal combustor by products. In addition, as a good example, this project promotes pollution prevention by using one waste stream in the treatment of a seçond one. We look forward to a successful conclusion to phase 2 .

Sincerely,

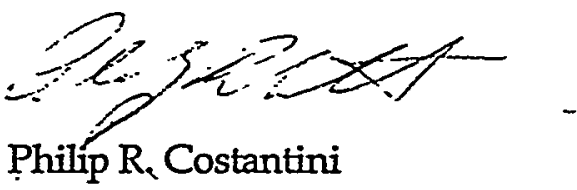

Executive Vice President and

Chief Financial Officer

\section{PRC:mat}

$\sqrt{c}$ Prof. J. Cobb, University of Pittsburgh

S. Renninger, U S DOE 


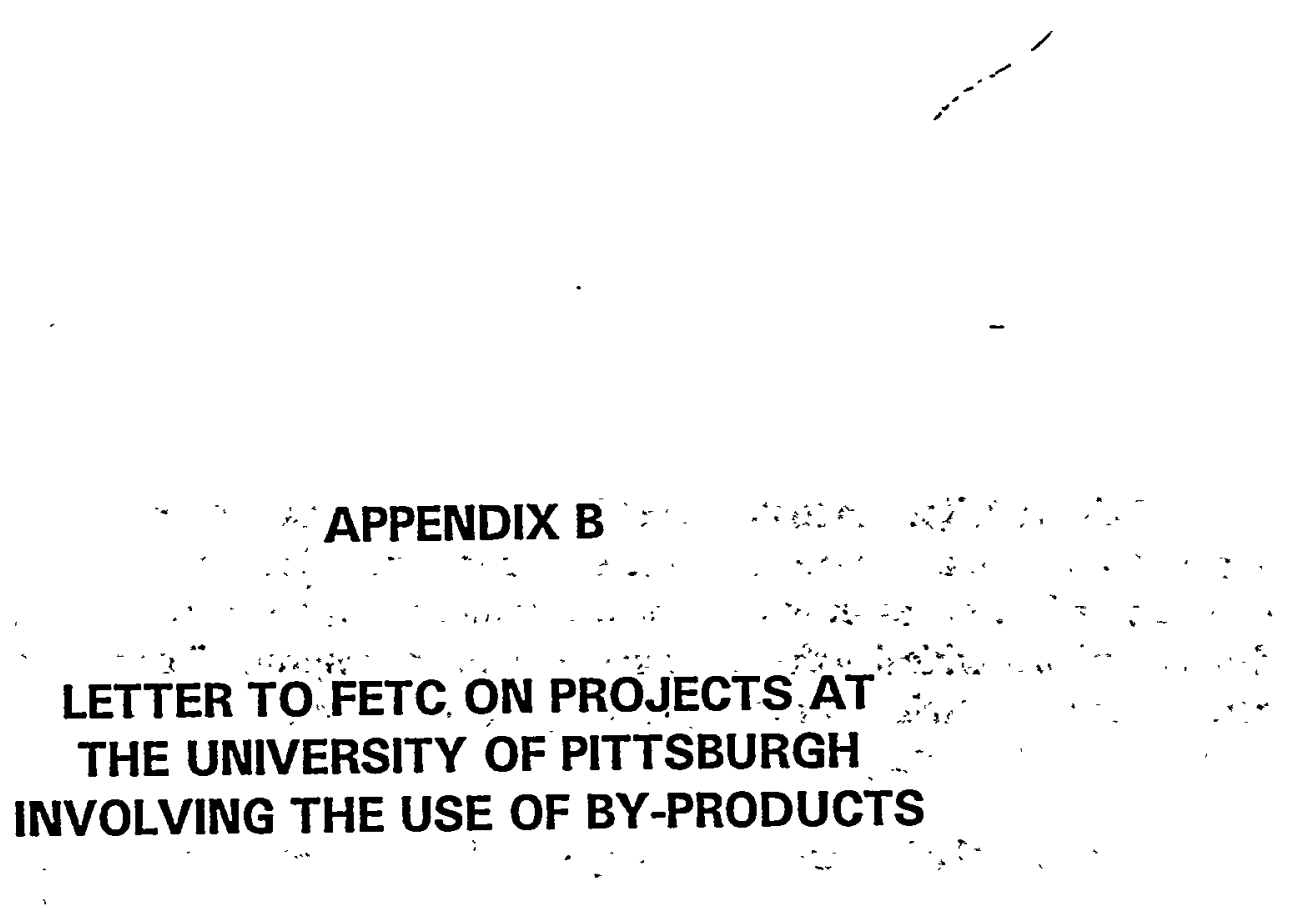




\section{University of Pittsburgh}

School of Engineering

Department of Civil \& Environmental Engineering

January 19, 1998
949 Benedum Hall

Pittsburgh, Pennsyivania 15261-2294

412-624-9870 Telephone

412-624-0135 Fax

Mr. William W. Aljoe

Environmental Engineer

U.S. DOE

Power \& Environmental Systems Division

626 Cochrans Mill Road

P.O. Box 10940

Pittsburgh, PA 15236-0940

Dear Bill:

This is a follow-up to the DOE "By-Products Utilization" meeting that Jim Cobb and I attended last month. We are pleased to see a consortium forming to further the utilization of byproducts, and we are eager to participate in as broad a manner as possible. While research and demonstration is critical in the commercial sector, an "outgrowth" of academic involvement is the contemporaneous training of young engineering professionals who are capable of carrying and implementing the message of energy by-product utilization into the future.

The School of Engineering faculty has a long history of working with DOE in the research and development of environmentally acceptable energy systems. In addition, I would like to bring to your attention a number of current projects within the University of Pittsburgh Department of Civil \& Environmental Engineering, and Department of Chemical \& Petroleum Engineering involving the innovative use of by-products. For example:

- Scott Renninger is supporting us in an effort to demonstrate use of advanced clean coal technology by-products as treatment chemicals for hazardous waste stabilization. This project, an example of a moderate volume-moderate value use, will move this fall into its commercial demonstration phase (Phase 2) with Max Environmental Technologies, Inc., the reactivated private sector participant.

- An offshoot of this activity with graduate students has raised further questions of

(a) long-term aging and stability of previously encapsulated/stabilized heavy metals, (b) potentials for co-disposal of biological sludges with by-products (noting that anaerobic conversion of sulfates to sulfides is an excellent mechanism for heavy metal precipitation and stabilization), and (c) development of approaches to minimize the final total volume of the residual waste materialtreatment chemical matrix (a critical issue since the cost of disposal is highly sensitive to the volume/space required). 
- In initial discussions this past week with the Mill Service Yukon Plant of Max Environmental Technologies, Inc., concerning the plan for Phase 2, we learned that the product from the hazardous waste treatment with advanced clean coal technology by-products will be placed as the closure caps for impoundments 5 and 6 at the Yukon Plant. The set strength of the product therefore becomes an important factor. We wish to extend our laboratory work in Phase 2 to include assurance and evaluation of solidification as well as stabilization.

Recently, severe benthic sediment/sludge pollution (from historicalindustrial discharges) has been reported in the public press at "The Point", the headwaters of the Ohio River near downtown Pittsburgh. Calcium oxide has been used as treatment chemical in other locations for the stabilization of contaminated river and lake bottom sediments. We believe calcium-oxide containing advanced clean-coal technology by-products could do the same job, and are likely to be an economic and technical choice feed-stock for stabilization of dredged sediments leading to ultimate river-bed decontamination.

- At the December meeting, I provided you with copies of three ASCE Energy Division Journal articles describing our prior EPRI supported work in the area of high-flyash containing Autoclaved Cellular Concrete (ACC), a fairly high-yalue product. Accomplishments of this work ;: included chemical and physical characterization of the ACC block product, and definition of environmental parameters of metal and organic leaching and radon exhalation:? parameters considered necessary to achieve commercial acceptance of this new building material in the market place.

- Since we now have the necessary equipment including a high pressure steam autoclave to fabricate such ACC materials with varying recipes, a number of graduate students and undergraduates have "migrated" to this project. Unsupported work over the past year has included incorporation of polymer fibers for flexural strength enhancement, making of colored block materials, and inquiries into the use of high LOI (and ammonia containing) ash collected from low-NO $\mathrm{N}_{x}$ emitting electric utilities as an ACC feedstock. During the past week, for preliminary graduate student experimental evaluation purposes, we received about $450 \mathrm{lbs}$. of by-product from the Stanton Florida (Boiler \#2) electric utility where $\mathrm{NO}_{x}$ control is effected using a combination of low $\mathrm{NO}_{x}$ (lower temperature) combustion with Selective Catalytic Reduction. Personally, I feel that ACC may well be marketed as a high performance building product that incidently is made from high LOI clean-coal technology byproducts as feed stocks, however this needs to be comprehensively demonstrated. Furthermore, we need to examine potentials for incorporation of PM-2 $1 \frac{1}{2}$ by-products where many of the particulates may contain metals in levels higher than current flyashes (which may be locked away as a precipitate or complex in the ACC concrete-like matrix), and many of the fine particulates may be the result of ammonium sulfate and ammonium bisulfate condensation. 
- The geotechnical faculty of the Department of Civil \& Environmental Engineering has long term interests in flowable fills. Use of FGD and other sludges for such applications was demonstrated to the group during our December meeting at the St. Vincent College. Further research linking both physical and environmental properties of these and similar materials and applications should be undertaken before they can become accepted products for extended commercial use.

- On the international front, Dr. Cobb and I have been interacting with Gary Stats who, with AWD funding, supported the visit of Dr. Shiv Dube from the Center for Power Efficiency and Environmental Protection of the National Thermal Power Corperation Ltd., India visit to FETC and Pitt. Dr. Dube is now back in India, and we are currently exploring possibilities of involving the University of Pittsburgh in furthering incorporation of American technology in the utilization of Indian by-products by creating a project involving some graduate students at ITT Delhi and others coming to the University of Pittsburgh.

The above are current areas of faculty activity and interest. We are keenly desirous of conducting further research at both the academic and field levels.

I look forward to an opportunity to again meet with you, and to develop an: implementation plan and proposal for further research.

Best personal regards; ;

$$
\text { ards; }
$$

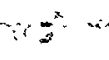

$\because \ldots, z$
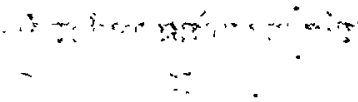

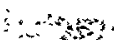

$\therefore ?$

$\therefore=$

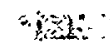

Sincerely,

Ronald D. Neufeld, Ph.D., P.E., DEE

Professor of Civil \& Environmental Engineering Environmental Engineering Program

cc: James T. Cobb Jr.; P.E.-Department of Chemical \& Petroleum Engineering 


\section{APPENDIX C}

LETTER TO BURNS AND ROE SERVICE CORPORATION ON A POTENTIAL ROLE FOR THE UNIVERSITY OF PITTSBURGH IN THE U.S.AID/U.S.DOE INTERAGENCY PROGRAM WITH INDIA 


\section{University of Pittsburgh}

SCHOOL OF ENGINEERING

Chemical and Petroleum Engineering Department

March 2, 1998

Dr. Roger Rao

Burns and Roe Service Corporation

P. O. Box 18288

Pittsburgh, PA 15236

Dear Dr. Rao:

Professor Ronald Neufeld and I greatly appreciated meeting with you and Dr. Radha Krishnan on February 13, 1998 to hear your thoughts about the U.S.AW/U.S.DOE interagency agreement for assistance to the electric utility sector of India. In this letter we offer ideas and suggestions for a new element of the program, which will deepen and enrich the exchanges that are already taking place.

We understand that the interagency agreement has the vision that ultimately throughout India there will exist a set of efficient; clean, reliable electric power stations, producing fully utilized by-products. We further understand that an important goal of the agreement is the comprehensive, collegial transfer to Indian utilities of concepts, designs and procedures that have been developed and demonstrated in the United States. The University of Pittsburgh suggests that an important and useful new strategy to reach this goal is to bring together academics and industrialists from India and the United States for a scholarly examination of policies, systems, technologies and practices.

Professor Neufeld and I therefore propose that we take action to establish a "U.S.India University/Industry Collaborative Program for Electric Utility Progress" within the framework of the interagency agreement. We currently envision that elements of this collaborative program might be:

- Bilateral seminars in India, first on broad technical topics, such as advanced power systems, power efficiency, sustainable energy, environmental protection, greenhouse gas reduction, and by-product utilization, and eventually on power generation and distribution policies.

- Consultations in India by U.S. academics and industrialists on specific technical topics, such as by-product utilization, advanced power systems, environmental controls, transportation, natural gas production and utilization, and analytical laboratory equipment selection. 
Letter to Roger Rao

March 2, 1998

Page Two

- The latter topic is of immediate importance. CENPEEP wishes to establish a comprehensive set of coal analyses in one of the research laboratories of NTPC to eliminate the costly, time-consuming shipment of samples to laboratories at Indian universities and overseas. A project on this topic within the collaborative program would assist in preparing equipment specifications and identifying vendors.

- Another topic of great interest is the control of water pollution from ash piles and ponds.

- A third topic is the siting of cooling towers and design of switchyards, such that the water droplet-laden plumes from the cooling towers do not adversely impact switchyards downwind.

- Study, research and teaching visits by faculty and key industrial staff to exchange general information, collaborate on research projects, and share insights on power generation and environmental protection.

- Graduate education for Indian students in the United States and U.S. students in India, and training for utility staff by U.S. experts in India.

- Key participants in the "U.S.India University/Industry Collaborative Program for Electric Utility Progress" might be:

- Engineering Center for Environment and Energy (ECEE), School of Engineering, - University of Pittsburgh, which would organize.and direct the program. The ECEE, described in Attachment $I$, is a tenure stream-faculty driven coordinating body whose mission is to facilitate and promote multidisciplinary joint activities across departments on the School of Engineering. The coordinating committee of the center has recently prepared an inventory of the School's activities in environment and energy. Attachment II

- summarizes the projects that are being conducted by the School's faculty.

- University Center for International Studies (UCIS), University of Pittsburgh, which will provide the ECEE with a university-wide support system for enriching and advising the "U.S./India University/Industry Collaborative Program for Electric Utility Progress." The India Studies Program, directed by the Asian Studies Program - a major element of UCIS, provides students at the University with training in languages of India and in area studies through a variety of courses and seminars. Attachment III describes the India Studies Program and two of its special elements - (1) a lecture series on "Fifty Years after Independence: Reflections on India Today" and (2) "Pitt in India," a 10-week summer study abroad program, whose first offering will take place this year in Hyderabad. 
Letter to Roger Rao

March 2, 1998

Page Three

- Centre for Power Efficiency and Environmental Protection (CENPEEP), National Thermal Power Corporation, Ltd., which is coordinating Indian participation in the activities of the interagency agreement. Dr. Shiv K. Dube, Manager of CENPEEP, has just completed a six-month visit at the University of Pittsburgh, where he was a Research Associate in the Chemical and Petroleum Engineering Department, assigned principally to the by-product utilization project being conducted by GAI Consultants, Inc. While he was here, I worked closely with Dr. Dube to introduce him to various professional groups and to counsel with him on his vision for CENPEEP.

- Indian Institute of Technology Delhi, with whom the School of Engineering is developing a formal relationship. We are in the midst of the second exchange of letters with Prof. V. S. Raju, Director of ITT Delhi, expressing mutual interest in a partnership and providing details of capabilities.

Professor Neufeld and I suggest that the team eventually include specialists from a number of U.S. universities, initially including ours, CMU, WVU, Penn State, Lehigh, U. Ky, and SIUC; U.S. utilities, such as AEP, APS, Southern Companies and TVA; and Indian organizations, such as CENPEEP, NTPC, CSIR, IIT Delhi and Jian University in Delhi. Funds for its operation would come initially through the interagency agreement, but other sources may be tapped as well. Our relation with IIT Delhi in all aspects of electric power and environmental protection would be the key one, although our connection with Jian University on policy matters would be very important. But we would also want to involve other universities in India that have existing or logical connections to power stations across the country, as well as certain of the 1600 NGOs that have spring up recently all across the subcontinent.

The first step toward formal creation of the collaborative program to be headquartered in our School is the submission of this brief white paper describing our vision and capabilities. I understand that over the next few weeks you and Dr. Krishnan will share this paper with appropriate individuals in India. If all agree that the collaborative program should be formed, a formal proposal can be developed.

Upon initial funding, Professor Neufeld and I might spend several weeks, principally in Delhi, to organize the Indian portion of the team and to identify the first topics for seminars and consultations. Upon our return to the United States, we would begin drawing together the experts needed for instruction and consultations. The first topics would be expected to include climate change, analytical equipment for coal, proposal development and project management for highly-educated technical staff members of the Indian utilities, and improvements in water quality of the runoff from coal ash piles. NTPC is particularly interested in knowing what it takes to become a "green" utility. Parallel to the development of seminars and consultations would be creating a research and education program jointly with IIT Delhi. The faculty who would be 
Letter to Roger Rao

March 2, 1998

Page Four

involved in this program would be asked particularly to broadly examine the situation and challenges facing Indian electric utilities and to offer generic solutions.

We are very excited by the opportunities which the "U.S./India University/Industry Collaborative Program for Electric Utility Progress" offers to the University of Pittsburgh to enhance its activities related to India. We appreciate your sharing the ideas embodied in this letter with your colleagues within the framework of the U.S.AI/U.S.DOE interagency agreement. And we look forward to working with you to develop the concept of the collaborative program to fruition.

Sincerely,

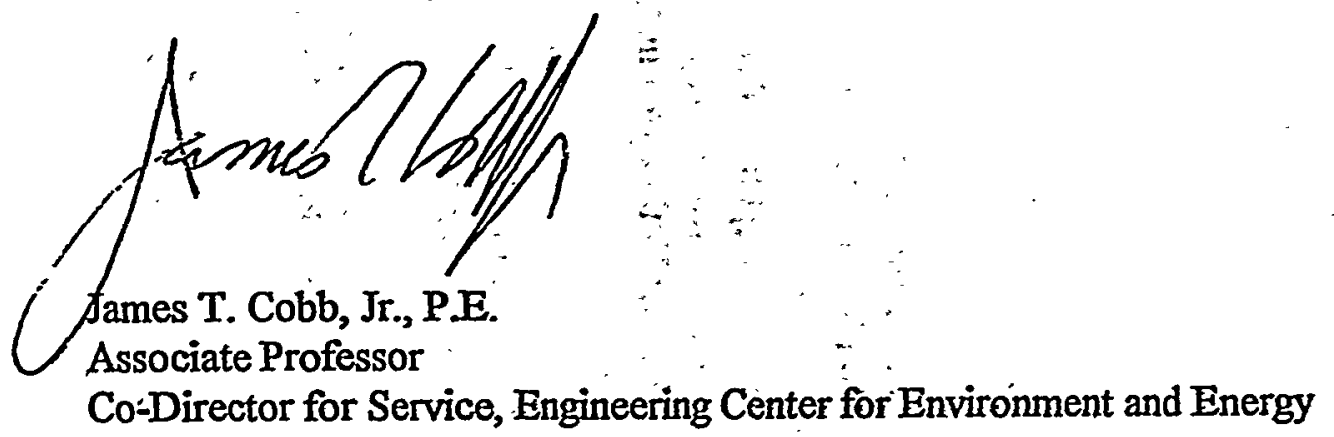

cc. Ronald Neufeld, Professor, Department of Civil and Environmental Engineering Alan Russell, Chair, Department of Chemical and Petroleum Engineering Rafael Quimpo, Chair, Department of Civil and Environmental Engineering Gerald Holder, Dean, School of Engineering

- Patricia Stranahan, Director, Asian Studies Program

Frederick Pohland, Weidlein Professor of Environmental Engineering and Director, Engineering Center for Environment and Energy 
- Electron Microscope Laboratory

4:Image/Pattern Recognition Laboratory

Participating Faculty.

ATAAI, Mohammad M.; Bioprocess engineering, immobilized enzymes BECKMAN, Eric J.; Environmentallybenign processes, supercritical fluids BIRKS, Neil; Hot corrosion/erosion;

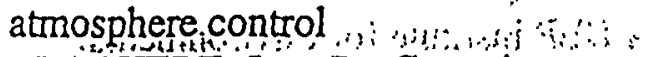
BLACHERE, Jean R.; Ceramics, , refractories, hot corrosion. BULLEN, A. Graham, R.; GIST, transportation systems

CASSSON, Leonard W.; Adsorption, fate and transport of particles and pathogens CHAPARO, Luis F.; Signal/image processing.

CHIANG, Shiao-Hung; Solid-liquid

$N$ separation, coal cleaning

CHUU, Chao-Lin; Hydraulics and hydrology COBB, James T., Jr.; MSW combustion, energy resources

COLCLASER, R.G.; Power Engineering transient analysis

d'ITRI, Julie L.; Environmental catalysis, surface chemistry, reaction kinetics FALK, Jóel; Öptical methodś, laser technology GOODWIN,'James G.; Cátály'sis,"; chemisorption HOLDER, Gerald D.; Phase behavior, gas hydrates wisind: : : :

HUNG, Tin-Kan; Fluid dynamics, bioengineering

HWANG, Charles C.; Multiphase heat

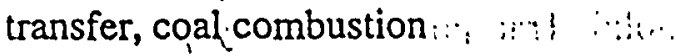

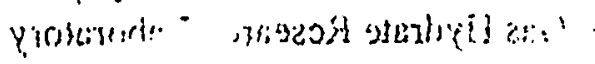

KLINZING, George E.; Particulate systems, solid transport?

KOLAR, Michael; Nuclear energy, electric power generation : . . :

LI, C:C.; Image analysis and pattern $: ; 0$ : recognition

MAZUMDAR, Mainak; Power, system

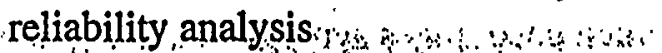
MEIER, Gerald H, Alloy oxidation, hot

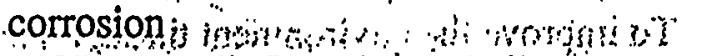
MORSI, Badie I Enhanced oil recovery, coal cleaning, reactor and process yn engineering is in NEUFELD, Ronald D.; Solid and hazardous waste management, industrial waste, $;$ biological processes

PETTIT, Frèderick S.; Hot corrosion, high temperature materials

POHLAND; Frederick G.; Solid and hazardous waste management, environmental impact assessment and remediätion

QUTMPO, Rafael, G.; Groundwater hydrology, water distribution systems RAJAGOPAí; $K$; Fluid dỹnamics, multiphase systems.

RUSSELL, Alàn.J.; Applied enzymology, biotechnology and protein'engineering

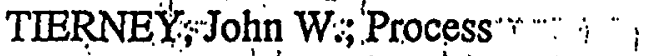
modeliñg/cóntrol,' cöäl liquéfảctión ... VALLEJO, Luis E.; Geotechnical engineering, geomènibränes, fracture

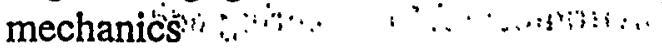
VIDIC, Radisavi D.; Physsical/chemicàl " processes; adsorption; flue gás'cleañ úp. WENDER; Irving; Catalýsis, coäl šciènce,

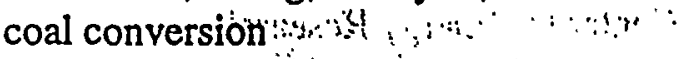

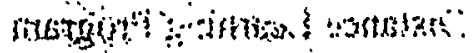

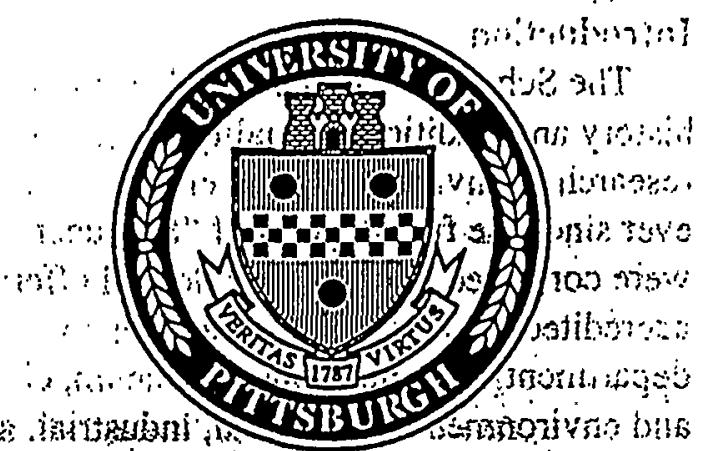

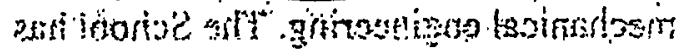

ENGINEERING CENTER FOR" ENVIRONMENTAND ENERGY

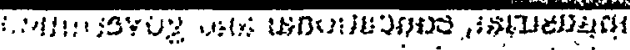

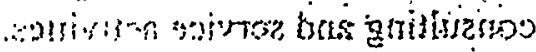

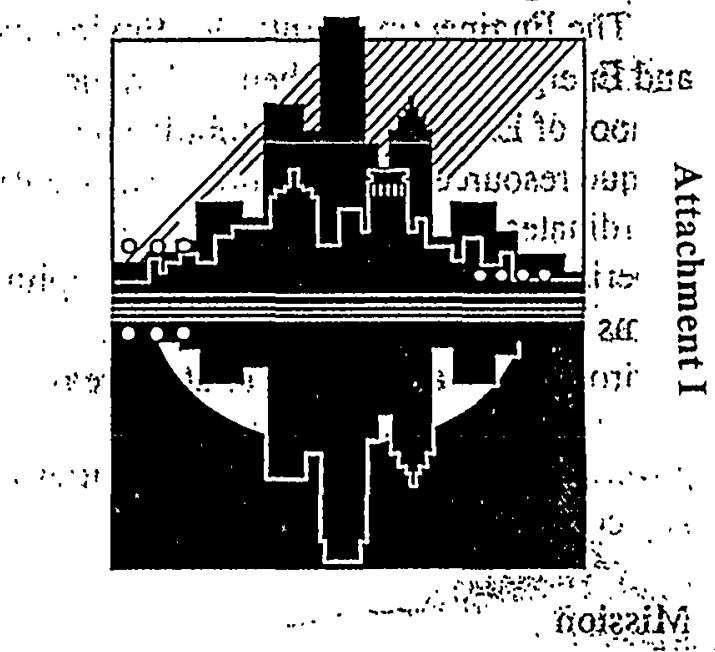

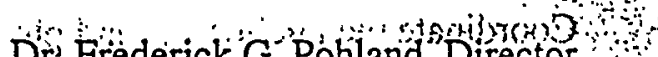
作 1140 Benedum Hall School of Engineering , wath University of Pittsburgh wim Pittsburgh, PA'15261, "sin

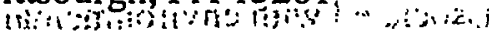
(412) $624-1880$ ming $f a x(412) 624-0135$ a 
Sintis.

Introduction

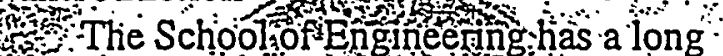
history and thadition of quality education and research in environmentand energy areas ever since the first degrees of "Engineer" were confened in 1846 the School offers accreditedengineening programs in six departments:chemical and petroleum, civil and environmentaj is electrical, industrial; and mechanical engineering. The School has" more than 100 full time faculty members; many of whom have hâd industrial experience and continue to participate nn Industrial, educational and government consulting and service activities.

The Engineering Center for Environment and Energy was established within the School of Engineering to mobilize the unique resources of the School. The Center coordinates the extensive expertise and experience of the faculty multidisciplinary teams forresolving criticâl issues in environimental and energy related areas. Collaboration with industrial partners, government agencies and public entities is a key component of Centeractivities

Coordinate the intellectual and physical resources of the school of Engineering with federal, state and local agencies, and with industries and the public to resolve technical, economomic, an social challenges associated with environmental and energy resources management, use and preservation. Goals

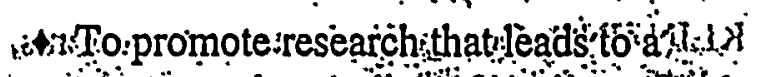
greater understanding of envifonmental:-

siand:energy resoüres.

- To encourage and promotè engineering: education of the highest quality in the environment and energy: foris

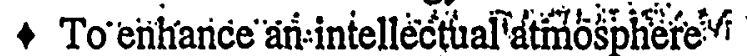
which encourages synergism and a global perspective as these relate to the Mission.

- To improve the environment through the

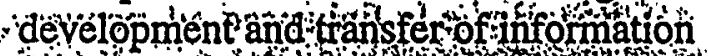
and new technoflogies to the loc national and international cominum

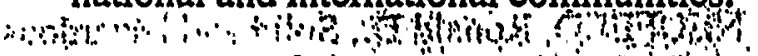

Organizátión Organization
$\therefore \quad: \quad, \ldots$, School of Englieering

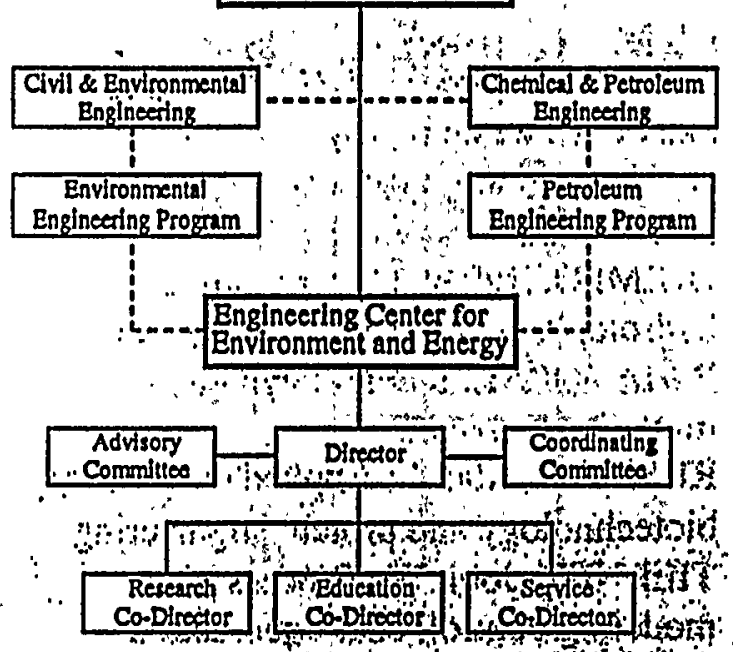

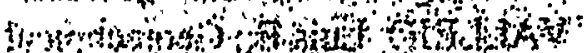

Representative Actipities

- Environmental Engineering and im trom Petroleum Engineering Progtams

- Interdisceiplinary! Eñvironmenental Engineering-Minor/Certificate Program/

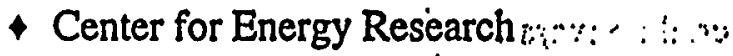

- Distance Learning Program.
- Pittsburgh:Cóal Conference somplial 4

- Nationál.Conference ôn Envînoñmental Engineering

- Environmental Colloquium and Poster: Fair

- Ground-Water Remédiätion Tèchnologies

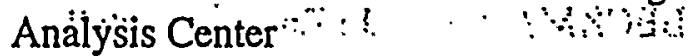

- Program in Environimeritally Cönscious" Procèssing

- PA DEP Institute for Ėnvirónmentital $T:$ Studies Institute for Fly As Research

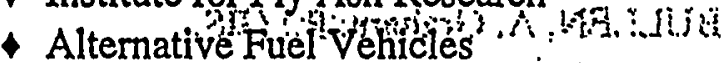
:

Facilities "Itr adition to modern teaching facilities with state of the art instructional equipment, the following facilities are available for environment and energy research at the School of Enginecring: - Environmentạ Microbiology and : $: \cdots$ Chemistry Laböratory

- Unit Operations and Processes

Laboratory

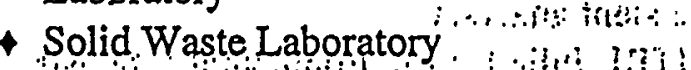

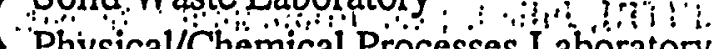

- Physical/Chemical Processes Laboratory

- Environmental Trace Substance Analytical Laboratory

pointitas

- Rèactor Engineering Laboratory

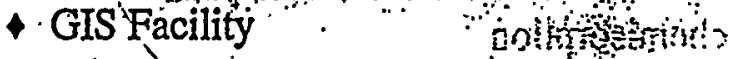

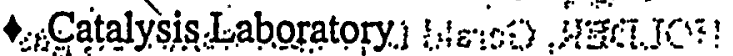

- Supercritical Fluids laboratory zsis: $; y_{i l}$

- Surface-Science Eaböratoryas

- Advanced Coal Processing!liaboratory il

- Coal Conversion'Laboratory ?

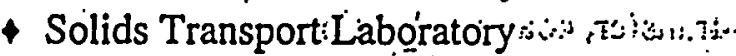

- Gas Hydrate Research Laboratory 


\title{
Attachment II
}

\section{ENGINEERING CENTER FOR ENVIRONMENT AND ENERGY (ECEE) Thrust Research Areas}

\begin{abstract}
Although the environment and energy activities at our neighboring institutions, as briefly summarized in Table 1, cover a wide spectrum of topic areas, ranging from policy analysis, management and training pertaining to science and technology of fossil fuels and environmental issues, the technology and process aspects, particularly those pertaining to industrial applications have received little emphasis.
\end{abstract}

Table 1: Environment and Energy Activities at Our Neighboring Institutions

\begin{tabular}{|c|c|}
\hline Institution & Activities \\
\hline Camegie Mellon University & $\begin{array}{l}\text { Green Design Initiative, Brownfields Revitalization, and Environmental and } \\
\text { Energy Policy Studies. }\end{array}$ \\
\hline Pennsylvania State University & $\begin{array}{l}\text { Emissions Reduction Research, Bioremediation and Detoxification, Energy } \\
\text { and Fuels Research, Coal and Organic Petrology, BioDiversity Research, } \\
\text { Artificial Intêlligence in Water Quality Control Processes, Gas Turbines and } \\
\text { Power Research. }\end{array}$ \\
\hline 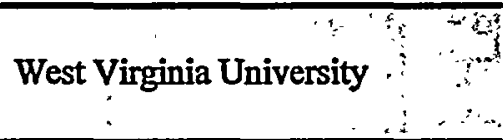 & $\begin{array}{l}\text { Longwall Mining and Ground Control Research, Appalachian Oil andNatural } \\
\text { Gas Résearch Consortium, National Research Center for Coal and Energy } \\
\text { (with an emphasis on Coal Conversion and Alternative Fuels). }\end{array}$ \\
\hline Duquesne University & $\begin{array}{l}\text { Education program in Environmental Science and Management through the } \\
\text { Bayer School of Natural and Environmental Sciences. }\end{array}$ \\
\hline
\end{tabular}

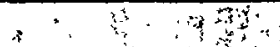

The thrust of the ECEE is in the development of integrated innovative technologies and processes for the protection of the environment and for the efficient use of energy resources. The mission of the ECEE includes emphasis on:

- Total System Integration (from Upstream to Downstream)

- Industrial Applications (Close Collaboration with Industries)

- Community Services (to Local, State and National Constituencies)

- Technology Transfer (through Education Training Programs)

- International Technology Export (with focus on Developing Nations)

Some of the current research activities in environment and energy being conducted by School of Engineering faculty involved with the ECEE are summarized in Table 2. The research activities can be classified into categories covering basic science, $\mathrm{CO}_{2}$ technologies, environmental technologies, biocatalyst use in environmental applications, industrial process development and control, outreach activities, and international research activities and cooperation. The anticipated outcomes and the benefits to potential sponsors are greatly dependent on the nature of the project. In general, technology transfer is being conducted in conjunction with each research activity. Activities 
involving conferences, publications and continuing educations are also summarized.

\section{Table 2: Current Research Activities of the ECEE Faculty 1995 -Present}

\section{Basic Science:}

\begin{tabular}{|l|l|r|l|}
\hline d'Itri & Hydrodechlorination of 1,2,3, - Trichloropropane & $\$ 29,750$ & Dow Chemical \\
\hline d'Itri & $\begin{array}{l}\text { Active Sites for Selective Catalytic Reduction of Nitrogen } \\
\text { Oxides }\end{array}$ & 15,000 & Exxon \\
\hline d'Itri & $\begin{array}{l}\text { Environmentally Benign Chemical Processing: A Theme for } \\
\text { the Future of Chemical Engineering }\end{array}$ & 60,000 & NSF \\
\hline Pettit/Meier & Hot Corrosion Testing and Evaluation of Aluminide Coatings & 44,893 & Howmet Corp. \\
\hline d'Itri/Hall & $\begin{array}{l}\text { Fundamental Aspects of Selective Reduction of NO }{ }_{x} \text { and Low } \\
\text { Temperature Methane Activation Catalyzed by metal- } \\
\text { containing Zeolites }\end{array}$ & 133,000 & DOE \\
\hline
\end{tabular}

\section{2. $\mathrm{CO}_{2}$ Technologies:}

\begin{tabular}{|c|c|c|c|}
\hline Chiang. & An Integrated $\mathrm{CO}_{2}-$ Based Process for Fluid/Solid Separation & $\$ 50,000$ & $\begin{array}{l}\text { Westinghouse/ } \\
\text { DOE }\end{array}$ \\
\hline Enick & $\begin{array}{l}\text { Mixing, Characterization and Flow Studies for the Carbon- } \\
\text { Dioxide-Based-Microsóntation of Recyclable Polyolefins }\end{array}$ & $\mathbf{7 , 7 0 0}$ & Normex Inc. \\
\hline Enick & $\begin{array}{l}\text { Formation Of Macromolecular Structures in Dense Carbon } \\
\text { Dioxide }\end{array}$ & 25,000 & $\begin{array}{l}\text { Am. Chem. } \\
\text { Society }\end{array}$ \\
\hline $\begin{array}{l}\text { Russell/ } \\
\text { Beckman }\end{array}$ & $\begin{array}{l}\text { Biocatalytic Polymer Synthesis in and from Carbon Dioxide } \\
\text { for Pollution Prevention : }\end{array}$ & 180,000 & EPA \\
\hline Enick/Beckman & Isolation of Metals Using Carbon Dioxide. & 63,100 & Normex Inc. \\
\hline Beckman & Reverse Micelles in Carbon Dioxide & 18,210 & $\begin{array}{l}\text { NSF/ } \\
\text { Oakridge Univ. }\end{array}$ \\
\hline Beckman & Supercritical $\mathrm{CO}_{2}$-Mediated Reactions on Polyvinyl Acetate & 42,000 & Air Products \\
\hline Beckiman & $\begin{array}{l}\text { Extraction and Purification of Proteins from Cell Broth Using } \\
\mathrm{CO}_{2}-\mathrm{Philic} \text { Surfactant/CO } \\
\text { Mixtures }\end{array}$ & 65,000 & Genencor Inc. \\
\hline $\begin{array}{l}\text { Beckman/ } \\
\text { Russell }\end{array}$ & $\begin{array}{l}\text { Design And Synthesis Of Co-Soluble Affinity Ligands and } \\
\text { Surfactants for Use in Carbon Dioxide Extractions }\end{array}$ & 50,000 & NSF \\
\hline Beckman & $\begin{array}{l}\text { Generation of Highly } \mathrm{CO}_{2} \text {-Soluble Chelating Agents for the } \\
\text { Extraction of Mercury from Mixed Waste }\end{array}$ & 65,028 & DOE - Sandia \\
\hline
\end{tabular}

\section{Biocatalyst in Environmental Applications:}

\begin{tabular}{|l|l|c|l|}
\hline Ataai & $\begin{array}{l}\text { Optimization of IMAC by Fine-Tuning Protein Metal } \\
\text { Interactions and Mathematical Modeling }\end{array}$ & $\$ 191,541$ & NSF \\
\hline Ataai & $\begin{array}{l}\text { New Strategies for Designing Inexpensive but Selective } \\
\text { Bioadsorbents for Environmental Pollutants }\end{array}$ & 92,297 & $\begin{array}{l}\text { Texas Univ./ } \\
\text { DOE }\end{array}$ \\
\hline
\end{tabular}




\section{Environmental Technologies:}

\begin{tabular}{|l|l|r|l|}
\hline Pohland & $\begin{array}{l}\text { Landfill Disposal of Creosote and Pentachlorophenol Treated } \\
\text { Wood Poles }\end{array}$ & $\$ 20,036$ & EPRI \\
\hline Pohland & Develop the INSIT Model for Soil and Groundwater & 25,000 & Gas Research \\
\hline Neufeld & Belt Filter Sludge Processing System & 83,000 & BFTC \\
\hline Klinzing & Assessment of Environmental Technologies & 10,000 & BFTC \\
\hline Beckman & Environmental Impact Of Polymer Processes & 100,000 & NSF \\
\hline Beckman & $\begin{array}{l}\text { Environmentally Conscious Manufacturing: Waste } \\
\text { Minimization In Chemical Processes }\end{array}$ & 575,000 & NSF \\
\hline Chiang & Oily Wastewater Treatment & 200,000 & DOE \\
\hline Casson & HIV in Wastewater: Presence and Viability & 16,363 & NSF \\
\hline Vidic/Beckman & $\begin{array}{l}\text { Development of Novel Activated Carbon-Based Adsorbents } \\
\text { for the Control of Mercury Emissions from Coal-Fired Power } \\
\text { Plants }\end{array}$ & 71,607 & DOE \\
\hline Cobb/Geiger & Wood/Coal Co-Firing in Industrial Stokers in Pittsburgh & 30,000 & USDA Forest \\
& Mechanical and Environmental Properties of Fly Ash & 40,000 & EPRI \\
\hline Neufeld & Mechan & \\
\hline
\end{tabular}

\section{Industrial Process Development and Control:}

\begin{tabular}{|c|c|c|c|}
\hline \begin{tabular}{cc|} 
Goodwin & $\ddots$ \\
\hdashline & $\cdots$ \\
\end{tabular} & $\begin{array}{l}\text { Attrition Resistant Fe Catalysts for Slurry-Phase Fischer- } \\
\text { Tropsch Synthesis }\end{array}$ & $\$ 125,000$ & $\overline{\mathrm{DOE}}$ \\
\hline Morsi & $\begin{array}{l}\text { Characterization of Mass Transfer In Cyclohexane Oxidation } \\
\text { Píocés's }\end{array}$ & 75,000 & DuPont \\
\hline Morsi - & $\begin{array}{l}\text { Mass Transfer in Slurry Bubble Columns with High Catalyst } \\
\text { Loading }\end{array}$ & 25,0000 & Exxon \\
\hline Billo/Bidanda & $\begin{array}{l}\text { A Computer Aided Rapid Diagnostic System for Blow } \\
\text { Molding }\end{array}$ & 77,516 & BFTC \\
\hline Mazumdar & Stochastic Models for Electric Power Production Costing & 200,680 & NSF \\
\hline Kim & $\begin{array}{l}\text { Manufacturing Technologies for III-V Refractory } \\
\text { Semiconductors }\end{array}$ & 31,100 & BFTC \\
\hline Needy/Bidanda & Development of a Smart Inventory Management System & 57,000 & BFTC \\
\hline Norman & Hot Rolling Process Control & 60,000 & BFTC \\
\hline Beck & $\begin{array}{l}\text { Reduced Modeling in the Control and Optimization of } \\
\text { Dynamic Systems }\end{array}$ & 10,000 & $\begin{array}{l}\text { Alcoa } \\
\text { Foundation }\end{array}$ \\
\hline
\end{tabular}




\section{Outreach Activities:}

\begin{tabular}{|l|l|c|l|}
\hline Pohland & Institute for Environmental Studies & $\$ 131,885$ & $\begin{array}{l}\text { PA Dept. of } \\
\text { Environmental } \\
\text { Protection }\end{array}$ \\
\hline Pohland & $\begin{array}{l}\text { Ground-Water Remediation Technologies Analysis Center } \\
\text { (GWRTAC) }\end{array}$ & 750,000 & $\begin{array}{l}\text { NETAC/Univ. } \\
\text { of Pittsburgh/ } \\
\text { EPA-TIO }\end{array}$ \\
\hline Wender/Tierney & Cooperative Research Program In Coal Liquefaction & 267,347 & $\begin{array}{l}\text { University of } \\
\text { Kentucky }\end{array}$ \\
\hline Eror & Cryoprocessing Institute for Advanced Materials & 96,278 & Argonne Labs \\
\hline Cobb & Natural Gas Vehicles Technical Assistance Project & 296,000 & $\begin{array}{l}\text { USFHWA/Penn } \\
\text { DOT/SPRPC }\end{array}$ \\
\hline Ataai & Research Experience for Undergraduates & 67,328 & NSF \\
\hline
\end{tabular}

\section{International Research Activities and Cooperation:}

\begin{tabular}{|c|c|c|c|}
\hline Goodwin & Comprehensive Chinese Program for Engineering & $\$ 298,606$. & NSEP \\
\hline Russell & $\begin{array}{l}\text { Biotechnology Versus Chemical Weapons: Implementation } \\
\text { of Enzyme Technology into Existing Decontamination } \\
\text { Techniques }\end{array}$ & 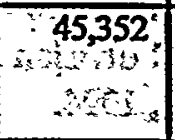 & $\begin{array}{l}\text { German } \\
\text { Ministy } \\
\text { Mastion }\end{array}$ \\
\hline Morsi & Mass Transfer in Toluene Oxidation Process & 30,000 & Squimed, \\
\hline Morsi & $\begin{array}{c}\text { Modeling and Optimization of Toluene Oxidation Process } \\
\text {. }\end{array}$ & $27,000^{\circ}$ & $\begin{array}{l}\text { LABO-Huiles, } \\
\text { France }\end{array}$ \\
\hline Morsi & 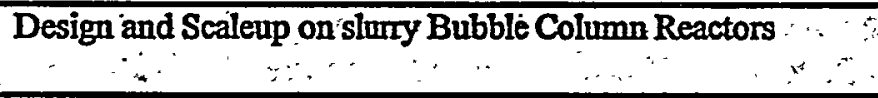 & $\therefore 60,000$ & $\begin{array}{l}\text { Sasol, } \\
\text { South Africa }\end{array}$ \\
\hline Chiu & $\begin{array}{l}\text { Hydrologic, Hydraulic and Sediment Studies for Reservoir } \\
\text { Sedimentation in Taiwan }\end{array}$ & 141,800 & MOEA Taiwan \\
\hline$\overline{C o b b}$ & Ash Utilization in India & 22,000 & $\begin{array}{l}\text { USAT/U.S.- } \\
\text { DOE/GAI } \\
\text { Consultants Inc. }\end{array}$ \\
\hline Chiu & $\begin{array}{l}\text { Development and Application of an Efficient Method of } \\
\text { Discharge Measurements in Rivers and Streams in Taiwan }\end{array}$ & 18,800 & $\begin{array}{l}\text { Ntl.-Chung- } \\
\text { Hsing Univ. }\end{array}$ \\
\hline
\end{tabular}

\section{Conferences and Colloquia:}

1. The Annual International Pittsburgh Coal Conference (The $14^{\text {th }}$ Conference was held in Taiyuan, China along with DOE workshop on September 23-28, 1997).

2. Annual Developments on Innovative Groundwater Remediation Technologies. The GWRTAC (Ground-Water Remediation Technologies Analysis Center) has been sponsoring an annual one-day conference since 1997.

3. National Conference on Innovative Technologies for Site Remediation and Hazardous Waste 
Management. The Conference was sponsored by Environmental Engineering Division of the ASCE, co-sponsored by the Canadian Society of Civil Engineering in cooperation with the a number of national and local organizations, and hosted by the University of Pittsburgh. The proceedings were edited by R. D. Vidic and F. G. Pohland (7/23-26, 1995).

4. The University of Pittsburgh Environment and Energy Colloquium and Poster Fair. The $4^{\text {th }}$ Environment and Energy Colloquium and Poster Fair, sponsored by the University of PittsburghSchool of Engineering, was organized by the ECEE and held on October 29, 1997.

\section{Books and Publications:}

1. Emerging Technologies in Hazardous Waste Management VI, Amer. Ácad. Of Envir. Engrs. (edited by D. W. Tedder and F. G. Pohland), 1996.

2. Emerging Technologies in Hazardous Waste Management V, ACS Symposium Series No. 607 (edited by D. W. Tedder and F. G. Pohland), 1995.

3. Emerging Technologies in Hazardous Waste Management as a result of 1994 Symposium of the $\mathrm{I}$ and EC division of the ACS Symposium Series No. 554 (edited by D. W. Tedder and F. G. Pohland), 1994.

4.

4. WASTECH Monograph Series (Phases D) on Innovative Site Remediation Technology: Process

Description and Limitations (F. G. Oohland, Chair; Steering Committëe), 1994.<smiles>[C+]1[CH]CCC1</smiles>

5. WASTECH Monograph Series (Phases II) on Innovative Site Remediation Technology: Design and Application. (F. G. Pohland: Chair, Steering Committee), 1997-98.

6. Hazardous and Industrial Wastes: Proceedings of the Twenty-Third Mid-Atlantic Industrial Waste Conference, (edited by R. D. Neufeld and L. W. Casson, 1991)

7. Coal-Energy and the Environment: Proceedings of the Annual International Pittsburgh Coal Conference, Volumes 1-14, University of Pittsburgh, 1984-1997 (Volumes 10-14 edited by S.-H. Chiang).

\section{Continuing Education:}

1. Soil and Ground Water Contamination/Remediation (Dr. F. G. Pohland, Department of Civil and Environmental Engineering. University of Pittsburgh).

2. Conventional Drinking Water Treatment (Dr. L. W. Casson, Department of Civil and Environmental Engineering. University of Pittsburgh).

3. Physical/Chemical Processes in Environmental Systems (Dr. R. D. Vidic, Department of Civil and Environmental Engineering. University of Pittsburgh). 


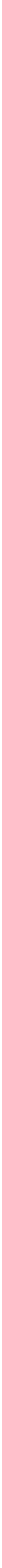



Pittsburgh (Pitt) is dedicated to promoting knowledge about the history, society, and culture of India, one of the world's most dynamic and influential nations. To that end it provides training in some of the languages of India and in area studies through a variety of courses. The India. Studies Program encourages multidisciplinary and interdisciplinary research, and facilitates the exchange of ideas and information tbrough seminars, conferences, and outreach activities for members of both the academic and local communities. These activities are directed by the Asian Studies Program (ASP) at Pitt, part of the University Center for International Studies.

One of the most valuable resources to the continued growth of India Studies at Pitt is the Pittsburgh Indian community.' The Pittsburgh area is home to the ninth-largest Indian population in. the United States. The western PA region has five temples to serve this community: the Jain-Hindu Temple; the Sri Venkateshwara Temple; the Sikh w Gurudwara; the Sri Sai Baba Temple; and the Iskcon (Hari Krishna) Commune. There are also two South Asian Moslem centers in the area.

In addition, two local foundations are active in supporting India. Studies in the area: the Kodenkandeth Foundation; which is dedicated to enbancing sensitivity to cultural pluralism; and the . Indian Heritage Research Foundation.

$$
\because \ldots . \cdots \cdots
$$

Pitt has been a member of the American Institute of Indian Studies since 1979. Pitt is also home to the Centey for the Performing Arts of India which sponsors many classical music and dance-drama events throughout each year. The University has also supported the Encyclopedia of Hinduism Project.

Béginning in 1996 India Studies at Pitt will SPONSOr a SUMMER INSTITUTE IN INDIAN STUDIES. The Instirute will offer four classes: Music in South indla; Rellgion \& Civillzation in South Asla; specific faculty membiers.

FINE ARTS

\section{. HISTORY}

Art. of Indla; and Culturés \& Sioclettes of India: All of the classes may be taken during a twelve week period.

\section{OURSES}

\section{UNCOMMONLY TAUOHT LANOUAORS}

The Department of Linguistics, through the Language Acquisition' Institute "(LAD), offers opportunities for the study of languages not otherwise avallable in the University caurriculum. The Institute will undertake the development of a course of study for any modern languages for which adequate instructional materials exist, except for those which are taught in the regular foreign language departments of the University.

The India Studies Program offers a selection of courses from several departments in the College of Arts and Sciences students may pursue more advanced course work in India studes by enrolling in Independent studies courses with

\section{ANTHROPOLOGY : \\ 1764 Cultures \& Societies of India}

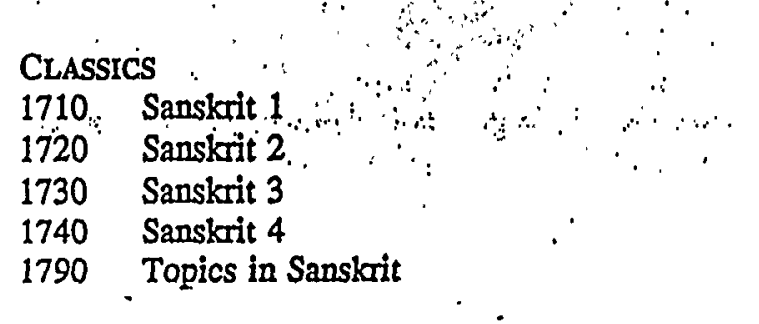

0700. Special Topics: India

0101 Art of India

0720 Hindu Ant ( $x$-listed w/RELGST 0517)

1700. Special Topics: India

1757 Religion in India I ( $x$-listed w/RELGST 1500).

1758 Religion in India II ( $x$-listed w/RELGST 1510)

Musrc :

RELIGTOUS STUDIEST

0515 Religion \& Civilization in South Asia

1500 Religion in Indial (x-listed w/HIST 1757) $\quad \cdots \cdots$

1510 Religion in India in (x-listed w/HIST 1758)

1516 Temple, Icon, \& Deity in India
Languages of India that have been offered in the recent past by the LAI include Hindi and Urdu.

\section{CERTIFICATE PROGRAMS}

Students enrolled in any $\mathrm{BA} ; \mathrm{MA}$, or $\mathrm{PhD}$ degree program in any department or professional school at Pitt may earn a Certificate in Asian Studies with a concentration on India. The certificate may be earned by American and international students and is especially helpful for those who want to focus their academic major on India.

The certificate is designed for students who wish to intensify their study of India-either because they intend to use their knowledge of that critical part of the world in their careers after graduation, or because they realize the importance of an understanding of Indian history, language and culture as part of their liberal arts education. Upon graduation, both the academic degree and CERTIFICATE IN ASIAN STUDIES are posted on the student's transcript.

Enrolling in the India Studies-focus certificate program allows students to earn another academic credential at no extra tuition cost and without additional investment in time or work. $: \because \cdots$

UNDERGRADUATE REQUTREMENTS for the India Studies concentration ASP certificate include :

1) Two years (four terms) of a vernacular Indian proficiency. If the Sanskrit language is chosen, only three terms are required to fulfill cerificate requirements.

2) Four courses (12 credits) on India in at least two departments outside the major. - language at the college level, or equivalent 


\section{Fifty Years After Independence: Reflections on India Today Lecture Series}

sponsored by

The Pitcairn-Crabbe Foundation

The University of Pittsburgh's Department of Religious Studies and Asian Studies Program

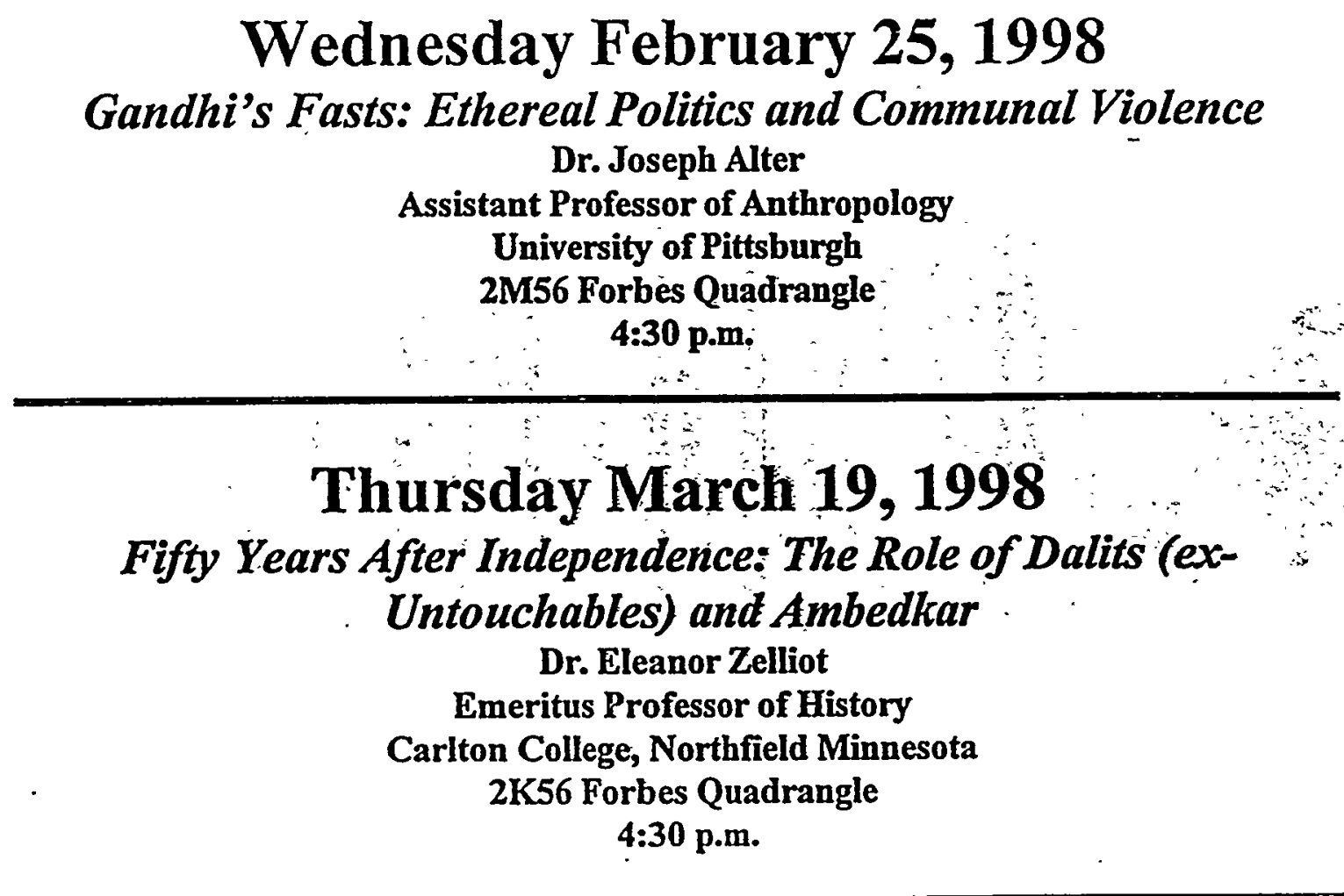

\section{Thursday April 2, 1998}

Hindu Nationalism and Independent Indians: 1947-1997

Dr. Walter Andersen

Division Chief

The Office of Analysis for Near East and Southeast Asia

U.S. State Department

2K56 Forbes Quadrangle

4:30 p.m. 

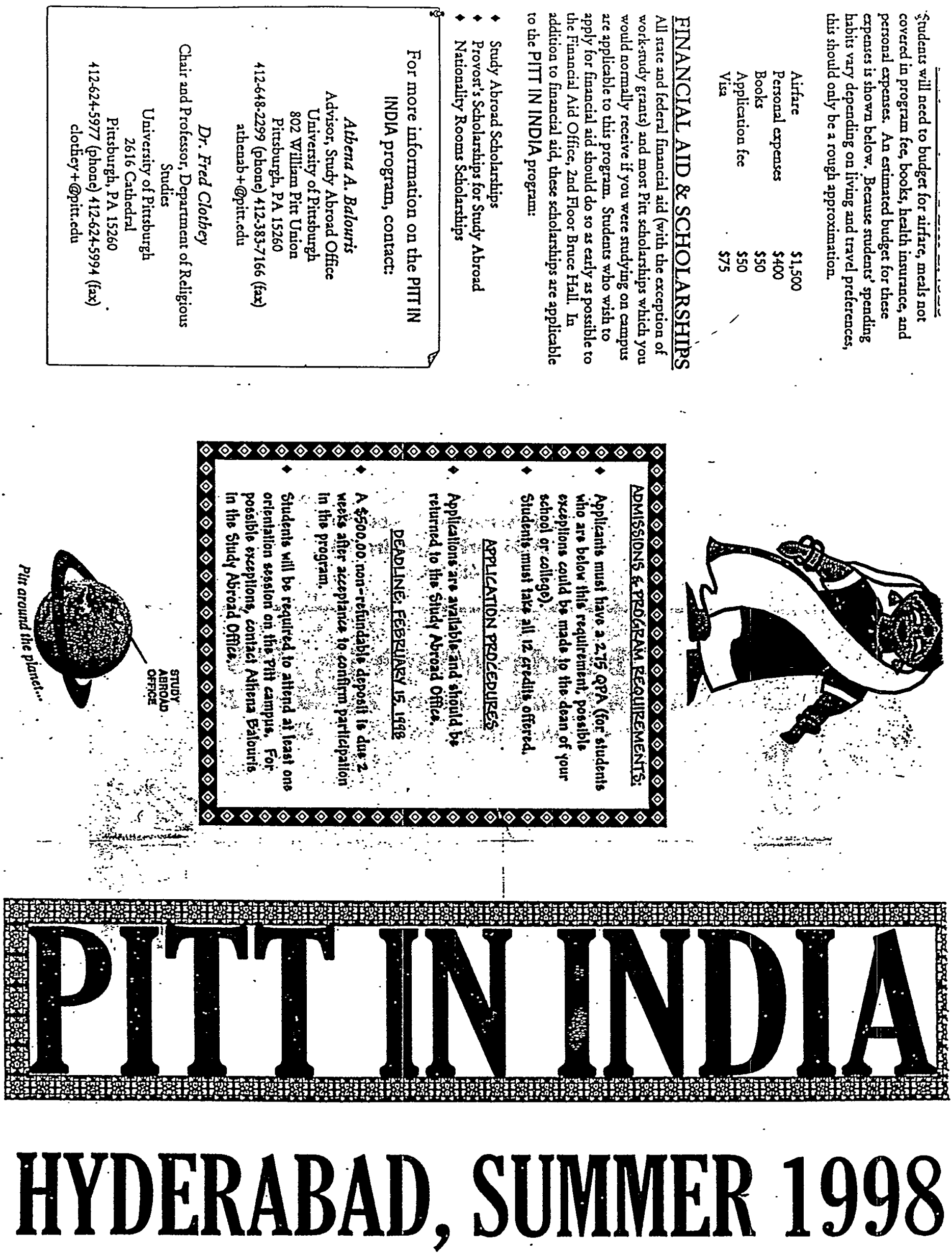
Join the University of Pittsburgh in
Hyderabad, India for Summer 1998! XXXXXXXXXXXXXXXXXXXXXXXXXXXXXXXXXXXXXXXXXXXXXX

he University of Pittsburgh is pleased to offer a 10-week summer study abroad program which ntroduces students to the fascinating country of tian. The program will be beld at the University of Iyderabad, a culturally rich city and university environment.

\section{HYDERABAD-THE CITY} city of Hyderabad is the fifth largest city in India with istory dating from the 14th century. From the 17th ough the 19th centuries it was one of the most opulent os in Asia. Today it is pluralistic, using four languages cially (Tclegu, Findi, Urdu, and English) and is a rocosm of Indian religious and ethnic diversity. The has a moderate climate and is home to five major versities and several research and cultural institutes.

\section{HYDERABAD-THE UNIVERSITY}

e University of Hyderabad is a azionally funded iversity founded in 1974. It is a strong research and ching university with a computerized library and an ernationally connected faculty. It is situated on a large npus outside Hyderabad.

$\omega$

\section{ACADEMIC PROGRAM}

ie program will be coordinated by Dr. Apara Rayaprol DD, Sociology, University of Pittsburgh). In addition, $\therefore$ Fred Clothey (Religious Studies), will accompany idenes as program facilitator. An additional 20 faculty in the University df Hyderabad are available for the ogram.

\section{COURSE DESCRIPTIONS:}

Ie PITT IN INDIA PROGRAM spans 10 wecks and nsists of 3 components, worth a total of 12 credits: I INTRODUCTION TO CENTRAL INDIA I ETHNOGRAPHY AND THE INDIAN LANDSCAPE I DIRECTED STURX PBOIECT
STUDENTS MUST TAKE ALL OF THE; 3 COURSES

ANTHROPOLOGŸ 1764: INTRODUCTION.TO CENTRAL INDIA

(Weeks 1-10: June 22-August 28) 3 CREDITS

The program begins with this coirse providing students with 2 general introduction to India with 2

multi-disciplinary approach, an intensive survey of the region, and how it reflects the history, culture, and geography of the subcontinent. Learning is largely through field trips and hands-on observation. Topies include;

- geographical and cultural history

- politics, literature, and artistic heritage

- linquisties and rudiments of language

- religious ind social landscape

- economic patterns

- effects of globalization, ethnicity, and urban and national policies

- contemporary culture including 2rtists, writers, directors, and ritual life

- future disections of India

SOCIOLOGY 1414: ETHENOGRAPFX AND THE INDIAN LANDSCAPE

(Weeks 1-4: June 22-July 17) 3 CREDITS

This course focises on developing skills in observing and interpreting the contemporary Indian landscape and providing an avenue to meaningful interaction with contemporary India. Topics include: .

$\rightarrow$ gender issues

- human rights

- minority issues

- development projojects :-

- religious pluratism.

DIRECTED.STUDY PROEECT Weeks 1-10: Iune 22-Auguist 28

Students have 2 options from which to choose:

(1) The student may pork closely with a faculty advisor to engage in 2 seading and resesent program on a topic of the student's interest. Topies ma hy be píesêlected or may. emerge from the introductory courses. Options may saige emerge from the introductory. coursest Options may OFFERED FOR A TOTAL OF 12 CREDITS:
Telegi culture, aspects of Islamic Studies, the role of women in Indian life, and so on. (3-6 CREDITS)

(2) The student will choose from one of the courses listed in the University's Study India Progrem (available only if 2 minimum of 3 students register per class). These courses include Intensive Hindi, Intensive Telegu, Indian religion, cinema, literature, dance, etc. (3-6 CREDITS)

\section{HOUSING/MEALS}

- (1)University guest houses are available for all students. Students will be housed in double rooms which have a private bath. Indian style food and hygenic water will be provided.

- (2) Students can also choose homestays with Indian families, the details of which will be negotiated ahead of rime. Indian style food and hygenic water will be provided.

$\$ 2,200$

\section{PROGRAM FEE}

For Pitt-students

$\$ 2,500$

For non-Pitt students

Fec includes:

1800

- Tuition and fees for 12 credits

- Housing and meals

- Field trips to various sites of cultural importance

- Students will also have access to bicycles at no charge

XXXXXXXXXXXXXXXXX 1998 PROGRAM DATES

Arrival date

Saturday, June 20

Classes starts

Monday, June 22

Classè's end

Friday, August 28

Departure date

Sunday, August 30

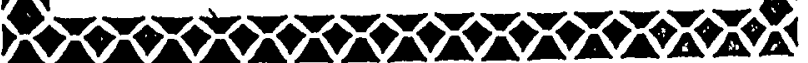

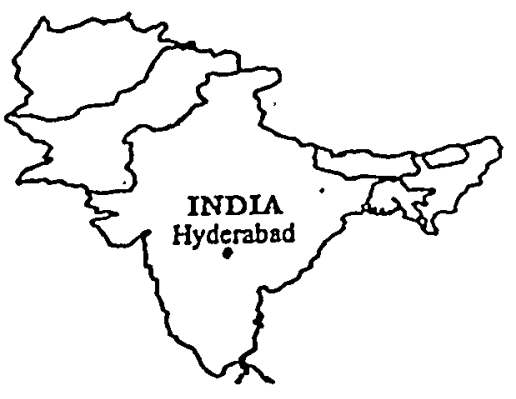

